\title{
MANAJEMEN PEMBERDAYAAN TENAGA ADMINISTRASI DI MTS AL-FATHIMIYAH TELUKJAMBE TIMUR KARAWANG
}

\author{
Siti Darojatun Nuhaya Dilah, Khalid Ramdhani, Abubakar \\ Universitas Singaperbangsa Karawang, \\ Korespondensi: Jalan HS Ronggo Waluyo, Telukjambe Timur Karawang 41361 \\ e-mail: darojatunnuhayadilla15@gmail.com
}

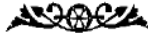

Abstract: The management of administrative staff empowerment at MTs Al-Fathimiyah Telukjambe Timur Karawang is the implementation of management functions in empowering administrative personnel, in order to improve the quality and professionalism of administrative personnel at MTs Al-Fathimiyah Teluk.jambe Timur Karawang. Among the management functions in empowering administrative personnel, implementing empowerment of administrative personnel and evaluating the empowerment of administrative personnel. The purpose of this study is to reveal or get a description of the empowerment management of administrative personnel at MTs Al-Fathimiyah Telukjambe Timur Karawang. The method used in this study is a descriptive research method with a qualitative approach. Data collection was carried out by documentation, observation, and interviews related to the object under study and then analyzed using qualitative descriptive analysis. The results of this study are as follows: 1) planning for the empowerment of administrative personnel at MTs AlFathimiyah Telukjambe Timur has been planned by the head of the madrasah. 2) organizing the empowerment of administrative personnel at MTs Al-Fathimiyah Telukjambe Timur bas been organized by the head of the madrasah, 3) the implementation of empowerment of administrative personnel at MTs Al-Fathimiyah Telukjambe Timur has been carried out at MTs Al-Fathimiyah Telukjambe Timur, 4) evaluating the empowerment of administrative personnel at MTs AlFathimiyah Telukjambe Timur has been evaluated by the principal of the madrasa. In other words, this study found that the management of administrative personnel empowerment at MTs AlFathimiyah Telukjambe Timur Karawang has been implemented using an empowerment management approach.
\end{abstract}

Keywords: Management, empowerment, administrative personnel

\section{PENDAHULUAN}

Pendidikan memiliki peranan penting dalam mengembangkan potensi sumber daya manusia secara optimal karena pendidikan merupakan sarana investasi untuk meningkatkan pengetahuan, keterampilan dan keahlian sebagai modal pembangunan bangsa. Pihak pemerintah juga terus berupaya untuk meningkatkan kualitas pembangunan pendidikan melalui kpengembangan dan perbaikan sarana pendidikan, kurikulum dan sistem evaluasi pengadaan materi ajar, serta pelatihan guru dan tenaga pendidikan lainnya.

Manajemen Pemberdayaan Tenaga Administrasi... | 
Dalam Ramdhani (2017: 206)

Manajemen telah menjadi topic pembicaraan dan pembahasan sejak lebih dari 2000 tahun yang lalu. Sejak sejarah manusia pertama, yaitu Nabi Adam as, sudah dibutuhkan adanya pemimpin yang dapat mengatur hubungan manusia. Nabi Adam as telah mendapat amanah dari Allah SWT. sebagai khalifah atau pemimpin untuk mengatur ekosistem alam semesta ini dengan baik. Sebagaimana dalam Firman Allah SWT:

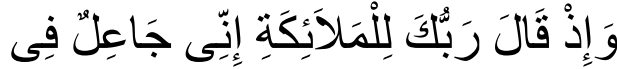
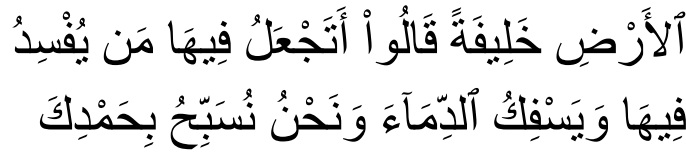

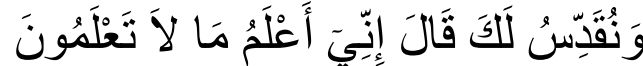

"Ingatlah ketika Tubanmu berfirman kepada para Malaikat "Sesunggubnya aku hendak. menjadikan khalifah di muka bumi. "Mereka berkata: "Mengapa Engkau bendake menjadikan (khalifah) di bumi itu orang yang akan membuat kerusakan padanya dan menumpabkan darah, padahal senantiasa bertasbih dengan memuji Engkau dan menyucikan Engkau?" Tuhan berfirman: "Sesungguhnya aku mengetabui apa yang tidak kamu ketahui." (Q.S.al-Baqarah:30)

Manajemen pendidikan Islam merupakan salah satu cara untuk meningkatkan kualitas kehidupan umat dari keterbelakangan baik secara moral, material, dan spiritual. Mengingat suatu sistem tidak akan sempurna bahkan tidak akan bisa berjalan sesuai apa yang diharapkan kecuali dengan adanya manjemen. Hal ini tampak dalam ungkapan bijak dari: Sayyidina Ali bin Abi Thalib:

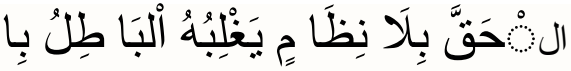

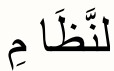

"Kebenaran yang terorganiosir dapat dikalabkan oleh kebathilan yang terorganisir".

Pemberdayaan merupakan kunci organisasi meningkatkan produktivitas dan kinerja organisasi. Sekolah sebagai organisasi pendidikan memiliki sumber daya manusia (SDM) yang menangani layanan administrasi, yang lazim disebut Tenaga Administrasi Sekolah (TAS).

Tenaga Administrasi Sekolah (TAS) merupakan ujung tombak pengelolaan administrasi di sekolah. TAS memiliki peran yang penting dalam pengelolaan sekolah, seperti tata persuratan sekolah, administrasi peserta didik, administrasi tenaga pendidik dan kependidikan, dan adminstrasi kurikulum.

Di MTs Al-Fathimiyah Telukjambe Timur Karawang jumlah pegawai tenaga administrasi berjumlah 8, dengan masingmasing personil memiliki tanggung jawab sebagai tenaga administrasi kurikulum, administrasi kesiswaan, bendahara, 2 (dua) staf TU, operator, dan administrasi sarana Prasarana. Semua personil masih berstatus sebagai pegawai tetap Yayasan AlFathimiyah dengan kualifikasi pendidikan S1/Sederajat. Masalah yang muncul di MTs Al-Fathimiyah yaitu masih banyak tenaga administrasi yang tidak sesuai dengan kualifikasi, tidak adanya kepala tenaga administrasi sekolah, padahal posisinya sangat penting karena sebagai pemimpin dalam pelaksanaan urusan tata usaha. Dan masih terdapat rangkap jabatan. Kurangnya pelatihan (Diklat) dari intansi yang terkait 
dalam rangka pengembangan kompetensi tenaga administrasi tersebut.

Berdasarkan fenomena diatas penulis terdorong untuk meneliti mengenai manajemen pemberdayaan tenaga administrasi. Dan permasalah yang akan dijawab dalam pembahasan ini adalah: 1) Bagaimana Perencanaan tenaga administrasi di MTs Al-Fahimiyah Telukjambe Timur Karawang. 2) Bagaimana Pengorganisasian tenaga administrasi di MTs Al-Fahimiyah Telukjambe Timur Karawang. 3) Bagaimana Pelaksanaan tenaga administrasi di MTs AlFahimiyah Telukjambe Timur Karawang. 4) Bagaimana Pengevaluasian tenaga administrasi di MTs Al-Fahimiyah Telukjambe Timur Karawang.

\section{KAJIAN TEORI}

\section{Manajemen}

Manajemen berasal dari kata "to manage" yang berarti mengelola. Pengelolaan dilakukan melalui proses dan dikelola berdasarkan urutan dan fungsi-fungsi manajemen itu sendiri. (Rohiat, 2010:14).

Ramayulis (1998:362), menyatakan bahwa pengertian yang sama dengan hakikat manajemen adalah al-tadbir (pengaturan). Kata ini merupakan derivasi dari kata dabbara (mengatur) yang banya terdapat dalam AlQuran seperti firman Allah SWT:

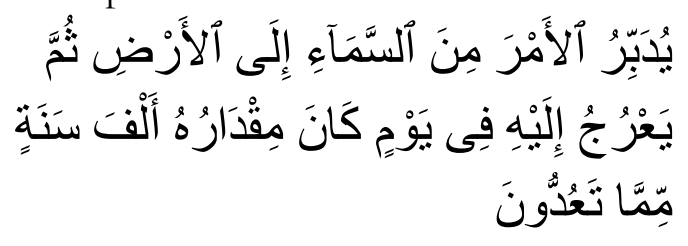

"Dia mengatur urasan dari langit ke bumi. Kemudian (urusan) itu niak kepadanya dalam satu hari yang kadarnya adalah seribu tahun menurut perbitungannya" (Q.S. As-Sajdah:5).

Dari ayat diatas diketahui bahwa Allah SWT merupakan pengatur alam. Akan tetapi, sebagai khalifah dibumi ini manusia harus mengatur dan mengelola bumi dengan sebaik- baiknya sebagaimana Allah SWT. mengatur alam raya ini.

Bahwa manajemen adalah sebuah usaha memanfaatkan berbagai sumber daya yang dilakukan sama-sama atau kerjasama dan diatur sesuai kemampuan dibidangnya, guna tercapainya tujuan bersama yang telah ditentukan.

a. Fungsi Manajemen

1) Perencanaan, Perencanaan merupakan suatu tindakan menetapkan terlebih dahulu mengenai apa yang akan dikerjakan akan dikerjakan, kapan akan mengerjakan, siapa yang akan mengerjakan, mengapa harus dikerjakan, apakah harus dikerjakan, dan bagaimana cara mengerjakan.

2) Pengorganisasian, Pengorganisasian merupakan proses bagaimana suatu pekerjaan diatur dan dialokasikan kepada para anggota agar tujuan organisasi dapat tercapai secara efektif dan efisien.

3) Pengimplementasian, adalah usaha membujuk orang melaksanakan tugastugas yang telah ditentukan dengan penuh semangat untuk mencapai tujuan institusi.

4) Pengawasan, pengawasan merupakan coercion atau compeling, artinya proses yang bersifat memaksa- maksa agar kegiatan- kegiatan pelaksanaan dapat disesuaikan dengan sesuai rencana

Manajemen Pemberdayaan Tenaga Administrasi... 


\section{Pemeberdayaan}

Menurut Syafii Antonio (2015:34), pemberdayaan (empowering) berhubungan dengan upaya pemimpin untuk menumbuhkan lingkungan agar setiap orang dalam organisasi perusahaan mampu melakukan yang terbaik dan selalu mempunyai komitmen yang kuat (committed).

Pemberdayaan adalah suatu upaya yang dilakukan oleh seseorang maupun kelompok melalui berbagai kegiatan pemberian keterampilan, pengembangan pengetahuan, penguatan kemampuan atau potensi yang mendukung agar dapat terciptanya kemandirian, dan keberdayaan pada pekerja baik itu dari segi potensi, ekonomi, sosial, budaya maupun pendidikan untuk membantu memecahkan berbagai masalah- masalah yang dihadapi, serta mampu melakukan yang terbaik guna tercapai tujuan organisasi dengan efektif dan efisien.

\section{a. Tahapan Pemberdayaan}

Menurut Isbandi Rukminto Adi (Aziz Muslim, 2012: 35-37), bahwa tahapan pemberdayaan terdiri dari 7 (tujuh) tahapan, diantaranya adalah sebagai berikut:

1) Tahap persiapan, yaitu petugas dan penyiapan lapangan. Penyiapan petugas dimaksudkan untuk menyamakan persepsi antara anggota tim fasilitator mengenai pendekatan yang akan dipilih. Sedangkan penyiapan lapangan dimaksudkan untuk melakukan studi kelayakan terhadap daerah yang akan dijadikan sasaran pemberdayaan.

2) Tahap assessment, tahap ini dimaksudkan untuk mengidentifikasi masalah yang dirasakan dan juga sumber daya yang dimiliki oleh masyarakat sasaran pemberdayaan.

3) Tahap perencanaan alternatif program atau kegiatan, pada tahap ini fasilitator secara partisipatif mencoba melibatkan masyarakat untuk berfikir tentang masalah yang dihadapi dan bagaimana cara mengatasinya. Dalam upaya mengatasi permasalahan yang ada masyarakat diharapkan dapat memikirkan beberapa alternative program dan kegiatan yang dapat dilakukan.

4) Tahap formulasi rencana aksi, pada tahap ini fasilitator membantu masing-masing masyarakat sasaran pemberdayaan untuk memformulasikan gagasan mereka terutama dalam bentuk tulisan bila ada kaitannya dengan pembuatan proposal yanga akan tunjukan kepihak penyandang dana.

5) Tahap pelaksanaan, pada tahap ini masyarakat mengimplementasikan agar apa yang telah dirumuskan bersamasama. Dalam upaya pelaksanakan program pemberdayaan memerlukan adanya peran dari masyarakat, dan fasilitator dengan masyarakat karena terkadang sesuatu yang sudah direncanakan dengan baik bisa melenceng saat dilapangan.

6) Tahap evaluasi, pada tahap ini dilakukan sebagai proses pengawasan dari masyarakat dan fasilitator terhadap program pemberdayaan yang telah dilakukan. Evaluasi sebaiknya dilakukan dengan melibatkan masyarakat bersamasama dengan fasilitator.

7) Tahap terminasi, tahap terminasi merupakan tahapan pemutusan 
hubungan secara formal dengan masyarakat yang menjadi sasaran pemberdayaan. Terminasi sebaiknya dilakukan jika masyarakat sudah bisa mandiri, bahkan dilakukan karena dana telah menghentikan bantuannya.

Dari penjelasan teori tahapan pemberdayaan yang dijelaskan oleh Isbandi Rukminto Adi, dapat diketahui bahwa tahapan pemberdayaan dapat diketahui bahwa tahapan pemberdayaan dapat dilakukan melalui 7 (tujuh) tahapan, meliputi tahap persipan, tahap assessment, tahap perencanaan alternmatif, tahap formulasi rencana aksi, tahap pelaksnaan, tahap evaluasi, dan tahap terminasi.

\section{Tenaga Administrasi}

Menurut Ngalim Purwanto dalam buku Yusak Burhanudin (1989) mengatakan bahwa administrasi adalah segenap proses pengarahan dan pengertian segala sesuatu, baik personal, spiritual dan material, yang bersangkut paut dengan pencapaian tujuan pendidikan.

Menurut Stephen J. Knezevich dalam bukunya Administration of Public Education mengemukakan bahwa pengertian administrasi sekolah adalah

"Scool administration is a process concerned with creating, maintaining, stimulating, and unifying the energies within an education toward realization of the predetermined objective" (Piet A. Sahertian, dkk, 1982:5)

"Administrasi sekolah adalah suatu proses yang terdiri dari usaha mengkreasi, melahirkan, menstimulir, dan mempersatukan semua daya yang ada pada suatu lembaga pendidikan agar tercapai tujuan yang telah ditentukan lebih dahulu”.

Dari pengertian di atas, penulis dapat menarik kesimpulan bahwa tenaga administrasi sekolah adalah sumberdaya manusia yang tidak terlibat langsung dalam proses belajar mengajar, namun sangat berperan penting dalam mencapai tujuan pendidikan, terutama dalam proses pengendalian, pengurusan, dan pengaturan adminstrasi sekolah.

Berdasarkan lampiran Permendiknas Nomor 24 Tahun 2008, secara lengkap tenaga Administrasi Sekolah ini terdiri dari Kepala Tenaga Administrasi SD/ MI/ SDLB: Kepala Tenaga Administrasi SMP/ MTS/ SMPLB: Kepala Tenaga Administrasi SMA/ MA/ SMK/ MAK/ SMALB: Pelaksana Urusan Kepegawaian, Pelaksana Urusan Keuangan, Pelaksana Urusan Administrasi Saran dan Prasaran; Pelaksana Urusan Administrasi Hubungan Sekolah dengan Masyarakat; Pelaksana Urusan Administrasi Persutratan dan Pengarsipan: Pelaksana Urusan Administrasi Kesiswaan; Pelaksana Urusan Administrasi Kurikulum.

\section{METODE PENELITIAN}

\section{Jenis dan Pendekatan Penelitian}

Metode penelitaian kualitatif, penelitian kualitatif adalah penelitian yang bermaksud untuk memahami fenomena tentang apa yang dialami oleh subjek penilitian, misalnya perilaku, persepsi, mivasi, tindakan dan lain-lain, secara holistic dengan deskripsi dalam bentuk kata- kata dan bahasa pada suatu konteks khusus yang 
alamiah dengan memanfaatkan metode ilmiah (Lexy Maleong, 2005:6)

Metode penelitian deskriptif adalah penelitian yang bertujuan mendeskripsikan atau menejelaskan sesuatu hal apa adanya dan metode ini memungkinkan peneliti memilih objek penelitian untuk dikaji secara mendalam dan hanya membuat peta umum dari objek penelitian (Prasetya Irawan, 1999: 60-61)

\section{Teknik Pengumpulan Data}

Teknik pengumpukan data yang dilakukan dalam penelitian ini dapat dijelaskan sebagai berikut

a. Wawacara, menurut Sugiono, (2009:194) Wawancara dilaksanakan dengan kepala sekolah, sie bidang kurikulum, sie bidang kesiswaan, dan dua tenaga administrasi sekolah untuk menggali atau mencari informasi secara lisan.

b. Observasi, menurut Suharsimi Arikunto (2010: 199) observasi adalah proses mengamati aktivitas kinerja tenaga administrasi sekolah serta sarana prasarana pendukung dalam bekerja.

c. Dokumentasi, Menurut M. Djunaidi Ghony \& Fauzan Almanshur (2012: 199) dokumen merupakan materi (bahan seperti: fotografi, video, film, memo, surat, diary, rekaman kasus klinis, dan sebagainyayang dapat menunjang sebagai informasi.

\section{Teknis Analisis Data}

Teknik analisis yang sesuai dengan penelitian ini adalah teknik analisis data secara interaktif, dengan langkah-langkah sebagai berikut: a. Reduksi data adalah merangkum, memilah hal-hal yang pokok, memfokuskan pada hal-hal yang penting, dicari tema dan polanya.

b. Penyajian data bisa dilakukan dalam bentuk uraian singkat, bagan, hubungan antar kategori, flowchart dan sejenisnya atau dengan teks yang bersifat naratif.

c. Penarikan kesimpulan dan verifikasi. Kesimpulan awal yang dikemukakan masih bersifat sementara, dan akan berubah bila tidak ditemukan bukti-bukti yang kuat yang mendukung pada tahap pengumpulan data berikutnya.

\section{HASIL PENELITIAN DAN PEMBAHASAN}

Dari temuan penelitian tentang manajemen pemberdayaan tenaga administrasi dapat diuraikan sebagai berikut:

\section{Perencanaan Pemberdayaan Tenaga Administrasi di MTs Al-Fathimiyah Telukjambe Timur Karawang}

Perencanaan pemberdayaan tenaga administrasi yang telah dilakukan oleh kepala madrasah di MTs Al-Fathimiyah Telukjambe Timur Karawang dapat dikatakan sudah cukup baik, hal ini dikarenakan kepala madrasah MTs Al-Fathimiyah Telukjambe Timur Karawang telaj menerapkan prinsioprinsip perencanaan pemberdayaan tenaga admunistrasi di MTs Al-Fathimiyah tersebut, seperti halnya kepala madrasah melakukan analisa profil pada perencanaan pemberdayaan tenaga adminitrasi, kepala madrasah merumuskan program-program kerja pada perencanaan pemberdayaan tenaga administrasi, kepala madrasah juga telah merumuskan arah dan tujuan yang 
hendak dicapai dalam pemberdayaan TAS di madrasah tersebut.

Keterangan di atas sejalan dengan pendapat Badriah (2007: 21) "Perencanaan merupakan proses penentuan langkahlangkah yang akan dilakukan dimasa datang, atau disebut juga sebagai proses pengambilan keputusan sekarang untuk sesuatu hal yang akan dilaksanakan pada waktu yang akan datang".

Berdasarkan hasil wawancara dengan kepala madrasah MTs Al-Fathimiyah Telukjambe Timur Karawang, beliau mengatakan bahwa perencanaan pemberdayaan tenaga administrasi yang telah ditetapkan dapat memberi manfaat yang banyak bagi madrasah tersebut, diantaranya: 1) Ada penentuan tujuan lembaga pendidikan sebagai tolak ukur perencanaan pemberdayaan tenaga administrasi

2) Adanya upaya meletakkan landasan kebijakan dan langkah-langkah operasional kerja tenaga administrasi yang tetap mengacu pada prinsip efektivitas dan efisiensi kerja pada madrasah tersebut

3) Adanya pengukuran kemampuan bagi efektivitas dan efisiensi kinerja tenaga administrasi dengan mempertimbangkan hasil-hasil yang telah diperoleh sebelumnya.

4) Adanya kepastian tindakan yang relevan dengan tujuan yang telah ditetapkan didasarkan pada pembinaan guru

5) Adanya harapan memperoleh kemajuan dalam kinerja dan profesionalisme

6) Adanya hasil yang direncanakan dengan standarisasi yang jelas.

Hal diatas sesuai dengan pendapat Hikmat (2009: 102) yang mengatakan bahwa manfaat perencanaan pendidikan pada lembaga pendidikan diantaranya:

1) Penetapan tujuan pendidikan sebagai tolak ukur

2) Upaya meletakkan landasan kebijakan dan langkah-langkah

3) Pengukuran kemampuan bagi efektivitas dan efaluasi kerja

4) Pengawasan dan penilaian terhadap hasil yang dicapai

5) Menghilangkan ketidakpastian sasaran dan tujuan pendidikan

6) Dapat dijadikan sebagai dasar penjabaran program kerja secara sistematis

Dengan demikian perencanaan pemberdayaan tenagaa administrasi sekolah yang telah ditetapkan kepala pada madrasah tersebut, diharapkan dapat mengukur kinerja para guru pada lembaga pendidikan tersebut, dan para guru dapat meningkatkan kinerjanya sehingga tenaga administrasi mempunyai kompetensi (kemampuan)untuk dapat diberdayakan secra maksimal.

\section{Pengorganisasian Pemberdayaan Tenaga Administrasi di MTs Al- Fathimiyah Telukjambe Timur Karawang}

Pengorganisasian pemberdayaan tenaga administrasi sangat perlu diperhatikan dalam keberlangsungan suatu organisasi sekolah/madrasah. Kepala madrasah AlFathimiyah telah melakukan pengorganisasian pemberdayaan guru melalui SK kepala madrasah yang ditetapkan pada madrasah tersebut. Dalam hal pengorganisasian pemberdayaan guru di Madrasah Tsanawiyah Al-Fathimiyah Telukjambe Timur Karawang, kepala 
madrasah

sebagai

manajer

mengimplementasikan

prinsip

pengorganisasian secara efektif, karena

kepala madrasah telah membagi tugas

bawahannya dalam berbagai unsur organisasi

secara proporsional, dengan kata lain kepala

madrasah telah membagi dan

menstrukturkan tugas-rugas tenaga

administrasi sekolah ke dalam sub-sub atau

komponen-komponen organisasi seperti memberi tugas dan wewenang kepada tenaga administrasi sekolah.

Hal di atas sesuai dengan pendapat Syaiful Sagala (2008: 49) yang mengatakan bahwa: "pengorganisasian yang efektif adalah membagi habis dan menstrukturkan tugas-tugas kedalam sub-sub atau komponen organisasi"

Pengorganisasian diartikan sebagai keseluruhan proses untuk memilih orangorang serta mengalokasikan saran dan prasarana untuk menunjang tugas orangorang itu dalam organisasi. Pengorganisasian juga dimaksudkan untuk mengatur mekanisme kerja organisasi, sehingga dengan pengaturan tersebut dapat menjamin pencapaian tujuan yang ditentukan. Keefektifan pengorganisasian kepala madrasah terlihat pada bagaimana kepala madrasah menggambarkan ketetapan pembagian tugas, hak, dan tanggung jawab, hubungan kerja bagian-bagian organisasi, dan menentukan personal dalam menjalankan tugasnya dan fungsinya. Sedangkan dalam keunggulan dalam pengorganisasian menggambarkan kemampuan organisasi dan kepala madrasah melakukan fungsi dan tugasnya sehingga meningkatkan kualitas madrasah.
Kepala madrasah jug atelah menjalankan prinsip pengorganisasian yatu kesatuan arah dari berbagai bagian organisasi yang konsisten terhadap visi dan misi madrasah, adanya kesatuan perintah, adanya kesatuan komando sehingga tidak kehilangan arah adanya keseimbangan antara wewenang dan tanggung jawab seseorang dalam menjalankan tugasnya.

Adanya pembagian tugas yang jelas dan tegas, struktur organisasi disusun sesederhana mungkin, pola organisasi relatip permanen, adanya jaminan terhadap jabatanjabatan dalam organisasi,adanya balas jasa setimpal diberikan setiap anggota organisasi, dan penempatan orang yang bekerja dalam organisasi sesuai dengan kemampuannya, walaupun banyak tenaga administrasi yang tidak sesuai dengan disiplin ilmu/bidangnya. Inilah penerapan pengorganisasian pemberdayaan tenaga administrasi yang diterapkan oleh kepala madrasah pada MTs Al-Fathimiyah Telukjambe Timur Karawang.

Jadi pengorganisasian pemberdayaan tenaga administrasi pada MTs Al-Fathimiyah Telukjambe Timur Karawang adalah tingkat kemampuan pimpinan/kepala madrasah dalam menentukan sasaran, pembagian pelaksanaan tugas, menentukan alat-alat yang diperlukan, pengalokasian waktu, dan menggunakan dana pemanfaatan sumber daya madrasah.

\section{Pelaksanaan Pemberdayaan Tenaga Administrasi di MTs Al-Fathimiyah Telukjambe Timur Karawang}

Pelaksanaan pemberdayaan tenaga
administrasi di MTs Al-Fathimiyah


Telukjambe Timur Karawang secara umum telah berjalan dengan baik, hal ini dapat dilihat dari hal-hal yang dapat dicapai dan terlaksana dari program kerja yang telah ditetapkan sebelumnya serta pelaksanaan tugas dan wewenang yang diberikan sebelumnya. Kepala madrasah sebagai manajer hendaklah menerapkan fungsi penggerakan sehingga anggotanya dapat menjalankan kebijakan pemberdayaan tenaga administrasi yang telah ditetapkan sebelumnya. Karena fungsi penggerakan akan dapat merangsang anggota-anggota kelompok melaksanakan tugas-tugas dengan antusias dan kemauan yang baik. Tugas menggerakan dilakukan oleh pimpinan, oleh karena itu kepala madrasah mempunyai peranan yang sangat penting menggerakan personilnya dalam melaksanakan program kerja madrasah yang telah ditetapkan sebelumnya.

Menggerakan adalah tugas pimpinan dan kepemimpinan. Menggerakan ialah kemampuan pimpinan mempengaruhi orang-orang mencapai tujuan yang telah ditetapkan dengan penuh semangat. Kepala madrasah juga sebagai manajer hendaknya menerapkan fungsi koordinasi agar anggotanya dapat menjalankan dan dapat melaksanakan dengan baik kebijakan pemberdayaan tenaga administrasi di madrasah MTs Al-Fathimiyah Telukjambe Timur Karawang.

Berdasarkan hasil wawancara dengan kepala MTs Al-Fathimiyah Telukjambe Timur Karawang, beliau mengungkapkan fungsi penggerakan dan pengarahan pada pelaksanaan pemberdayaan tenaga administrasi di MTs Al-Fathimiyah Telukjambe Timur Karawang melalui rapat koordinasi yang dilaksanakan pada setiap pertengahan semester dan rapat kerja pada setiap awal semester. Sejalan dengan hasil wawancara yang dilakukan dengan wakil kepala urusan kurikulum, beliau menerangkan bahwa kepala MTs AlFathimiyah Telukjambe Timur Karawang senantiasa menerapkan fungsi penggerakan dan pengarahan pada pelaksanaan pemberdayaan tenaga administrasi di MTs Al-Fathimiyah Telukjambe Timur Karawang. Dengan demikian palaksanaan pemeberdayaan tenaga administrasi di MTs Al-Fathimiyahn Telukjambe Timur Karawang telah terlaksana dengan baik fungsi manajemen, yaitu fungsi penggerakan dan pengarahan.

\section{Evaluasi Pemberdayaan Tenaga Administrasi di MTs Al-Fathimiyah Telukjambe Timur Karawang}

Pengevaluasian pemberdayaan tenaga administrasi di MTs Al-Fathimiyah Telukjambe Timur Karawang telah dilakukan kepala madrasah melalui analisa laporan kinerja tenaga admistrasi dan telah dibahas oleh kepala madrasah pada rapat akhir tahun, dan menurut hasil wawancara yang dilakukan dengan kepala madrasah mengenai manfaat pengevaluasian pemberdayaan tenaga administrasi, beliau menerangkan sebagai berikut:

1. Kepala madrasah dapat mengetahui perkembangan kinerja guru sebagai wujud pemberdayaan tenaga administrasi di madrasah

2. Kepala madrasah dapat mengetahui profesionalitas para tenaga administrasi dalam menjalankan tugasnya sebagai

Manajemen Pemberdayaan Tenaga Administrasi... $\quad 135$ 
wujud pemberdayaan tenaga administrasi di madrasah

3. Kepala madrasah dapat mengetahui kondisi objektif para pendidik berkaitan dengan tugas dang fungsinya masingmasing serta mengenai hak dan kewajiban sebagai wujud pemberdayaan tenaga administrsi di madrasah

4. Kepala madrasah akan mudah merencanakan strategi pemberdayaan guru untuk periode berikutnya

5. Sebagai acuan untuk menetapkan kebijakan untuk periode berikutnya dalam upaya pemberdayaan tenaga administrasi di madrasah.

Sejalan dengan hasil wawancara di atas, Saefullah (2012) mengatakan evaluasi sebagai berikut: "Evaluasi artinya menilai semua kegiatan untuk menemukan indicator yang menyebabkan sukses atau gagalnya pencapaian tujuan, sehingga dapat dijadikan bahan kajian berikutnya".

Evaluasi adalah fungsi manajmen merupakan aktivitas untuk meneliti dan mengetahui pelaksanaan yang telah dilakukan dalam proses keseluruhan organisasi mencapai hasil sesuai dengan rencana atau program yang telah ditetapkan.

Dalam upaya pengevaluasian pemberdayaan tenaga administrasi, kepala madrasah selaku manajer hendaknya melakukan pengendalian dan pengawasan, tugas ini adalah untuk meneliti dan mengawasi agar semua tugas dilakukan oleh semua dengan baik dan sesuai dengan peraturan yang ada atau sesuai dengan deskripsi kerja masing-masing personal. Pengendalian dapat dilakukan secara vertical maupun horizontal, atasan dapat melakukan pengontrolan dan pengevaluasian kepada bawahannya, demikian pula bawahan dapat melakukan upaya kritik kepada atasannya. Cara tersebut diistilahkan dengan sistem pengawasan. Pengawasan ini lebih menitikberatkan pada kesadaran dan keikhlasan dalam bekerkja.

Selanjutnya pengendalian yang dilakukan seorang manajer terdiri atas:

1. Penelitian terhadap hasil kerja sesuai dengan program kerja

2. Pelaporan hasil kerja dan pendataan.

\section{PENUTUP}

\section{Kesimpulan}

Dalam perencanaan pemberdayaan tenaga administrasi di MTs Al-Fathimiyah telukjambe Timur Karawang, dimulai dari menyusun program kerja tenaga administrasi. Dalam perencanaan ini kepala madrsah menyusun program kerja yang harus dilakukan para tenaga administrasi sekolah untuk satu tahun kedepanyang ditetapkan pada rapat pembagian tugas tenaga administrasi. Dengan demikian pemberdayaan tenaga administrasi sekolah di MTs Al-Fathimiyah Karawang sudah dilaksanakan dengan menggunakan pendekatan manajemen pemberdayaan.

Dalam pengorganisasian pemberdayaan tenaga administrasi di MTs Al-Fathimiyah Telukjambe Timur Karawang dilakukan dengan pemberian wewenang dan tugas kepada tenaga administrasi sekolah melalui SK penugasan dari kepala madrasah, adapun pengorganisasian pemberdayaan tenaga administrasi tersebut adalah: tenaga administrasi sekolah sebagai perangkat madrasah, dan uraian tugas yang telah direncanakan sebelumnya. Setelah kepala 
madrasah menyusun program kerja tenaga administrasi dan memberikan tugas dan wewenang kepada tenaga administrasi sekolah, mka tenaga administrasi melaksanakan tugas dan wewenang yang telah diberikan oleh kepala madrasah. Dengan demikian pengorganisasian pemberdayaan tenaga administrasi di MTs Al-Fathimiyah Karawang sudah dilaksanakan dengan menggunakan pendekatan manajemen pemberdayaan.

Pelaksanaan pemberdayaan tenaga administrasi dalam pemberian wewenang dan tugas oleh kepala madrasah telah dapat diberdayakan, namun pemberdayaan tenaga administrasi masih perlu ditingkatkan seperti tenaga administrasi kurikulum diberdayakan dengan mengikuti DIKLAT mengenai kurikulum. Tenaga administrasi kesiswaan diberdayakan dengan lebih meningkatkan kerjasamanya dengan wali kelas, perangkat madrasah lainnya, sehingga tidak timbul kesalah pahaman dalam penanganan kasuskasus siswa.

Dengan demikian pelaksanaan pemberdayaan tenaga administrasi sekolah secara umum sudah berjalan dengan baik, namun perlu ditingkatkan baik kualitas maupun kuantitasnya.

Pengevaluasian pemberdayaan tenaga administrasi di MTs Al-Fathimiyah Telukjambe Timur Karawang dilakukan dalam rangka melihat perkembangan kinerja dan kemajuan tenaga administrasi secara periodik. Menurut penjelasan kepala madrash evaluasi dilakukan pada rapat akhir tahun sebelum memulai tahun ajaran baru, evaluasi juga dapat berupa buku laporan dari masing-masing tenaga administrasi sekolah yang dilaporkan kepada kepala madrasah.
Dengan demikian pengevaluasian pemberdayaan tenaga administrasi sekolah di MTs Al-Fathimiyah Telukjambe Timur karawang sudah dilaksankan dengan menggunakan pendekatan manajemen pemberdayaan.

\section{KEPUSTAKAAN ACUAN}

Almanshur Fauzan, Ghony Djunaidi. 2012. Metodologi Penelitian kualitatif. JogJakarta: Ar-Ruzz Media.

Antonio Syafii. 2015. teladan Sukses dalam Hidup dan Bisnis. Muhammad SAW: The Super Leader Super Manager. Jakarta: Tazkia Publishing.

A Piet Sahertian. 2008. Konsep Dasar dan Teknik Supervisi.Jakarta : Penerbit Rineka Cipta.

Arikunto, Suharsimi. 2010. Prosedur Penelitian suatu Pendekatan Praktik. Jakarta: PT Bina Aksara.

Azis Muslim. 2012. Dasar-Dasar Pengembangan Masyarakat. Yogyakarta: Samudra Biru

Badriah. 2007. Human resource Managenemt for Secretay. Jakarta: Mitra Wacana Media.

Lexy J. Moleong. 2005. Metodologi Penelitian Kualitatif. edisi revisi. Bandung: PT. Remaja Rosdakarya Offset.

Permendiknas No. 24 tahun 2008 tentang Standar Tenaga Administrasi Sekolah/Madrasah.

Ramayulis.2008. Ilmu Pendidikan Islam. Jakarta. Kalam Mulia.

Ramdhani, Khalid. Penerapan Nilai-nilai pendidikan kepemimpinan di pondok

Manajemen Pemberdayaan Tenaga Administrasi... $\quad 137$ 
modern Darussalam gontorponorogo. Jurnal pendidikan islam rabbani. Vol.1, No.2, ISSN: 2549-337X. Available at: https://journal.unsika.ac.id/index.ph $\mathrm{p} / \mathrm{rabbani} /$ article/view/1027

Rohiat.2010. Manajemen Sekolah Teori Dasar dan Praktek. Bandung: PT Refika Aditama.
Saefullah.2012. Manajemen pendidikan Islam. Bnadung: CV Pustaka Setia.

Syaiful Sagala. 2009. Administrasi Pendidikan Kontemporer. Bandung: Alfabeta.

Yusak Burhanuddin. 1998. Administrasi Pendidikan. Bandung: CV Pustaka Setia.

138 | Jurnal al-Fikrah, Vol. VIII, №. 2 Juli-Desember 2020 